\title{
Austria-Hungary and the Ottoman Empire since the End of the Bosnian Annexation Crisis till the Italo-Turkish War ${ }^{1}$
}

\section{Roman KODET}

\author{
Katedra historických věd, Fakulta filozofická, Západočeská univerzita v Plzni \\ Department of Historical Sciences, Faculty of Philosophy and Arts, University of West Bohemia, \\ Tylova 18, 30125 Plzeň, Czech Republic \\ kodet@khv.zcu.cz
}

\begin{abstract}
Although the stabilization of the relations between Austria-Hungary and the Ottoman Empire after the end of the Bosnian annexation crisis created a possible base for the cooperation of both states, it had almost no impact on the turbulent political situation in Istanbul. On the contrary it was almost immediately after the end of the crisis when the complicated situation in the Ottoman capital came to its denouement. Even after the end of the Hamidiyan regime in the course of the Young Turk revolution, the old "Bloody Sultan" Abdülhamid II stayed on the throne and his popularity on the public even rose. ${ }^{2}$ His aim was however to destroy the new regime in Istanbul ${ }^{3}$ and restore his own rule. Trying to accomplish this goal he allied himself with the conservative Islamic circles which pursued the same policy. In the same time the liberal opposition led by the former Grand Vizier Kâmil Paşa violently attacked the new government of Hüsseyin Hilmi Paşa. Both Islamic conservatives and the liberals (who were in direct opposition in the Hamidiyan era) were quite concerned of the Young Turk dictatorship. Therefore a considerable number of manifestations and demonstrations against the Young Turk government had occurred since February 1909 on which demands of suspending the Constitution were sounded. The tense situation in Istanbul was even more dangerous because of the dissatisfaction of its military garrison. ${ }^{4}$

The climax of the public and military discontent in the Ottoman capital were the events at night of the 12 to 13 April 1909 when a huge crowd supported by 3,000 troops attacked the building of the Ottoman Parliament and called for the restoration of the Sultans
\end{abstract}

\footnotetext{
1 This study is a part of the grant project SGS-2013-044 "Rakousko-Uhersko a Orient na počátku 20. stoleti", which the author conducts at the Department of History, Faculty of Philosophy and Arts, University of West Bohemia in Pilsen.

2 Sean McMEEKIN, The Berlin-Baghdad Express. The Ottoman Empire and Germany's Bid for World Power 1898-1918, London - New York - Toronto 2011, 72.

3 To this question see Stanford J. SHAW - Ezel Kural SHAW, History of the Ottoman Empire and Modern Turkey. Volume II: Reform, Revolution and Republic: The Rise of Modern Turkey, 1808-1975, London - New York - Melbourne 1977, 274-279.

4 SHAW - SHAW, 279. Pallavicini discussed the situation with Kâmil Paşa on 17 March 1909. The ex-Grand Vizier told him that the Ottoman army experiences tough fight between two feuding factions. Österreichisches Staatsarchiv, Abteilung Haus-, Hof- und Staatsarchiv, Wien (hereinafter referred to only as HHStA), Politisches Archiv (hereinafter referred to only as PA), fund (f.) XII Türkei, cart.198, Berichte, Pallavicini to Aehrenthal, 17. 3. 1909.
} 
powers and punishment for the Young Turks leaders. ${ }^{5}$ These dramatic events alarmed the representatives of the Great Powers in Istanbul. The Austro-Hungarian ambassador Marquis Johann Pallavicini, who was one of the most respected diplomats of the Dual Monarchy, viewed the situation with great anxiety and described it as quite confused. ${ }^{6}$ As the most important event of those tumultuous days Pallavicini assessed the fall of Hüsseyin Hilmi Paşa and his replacement by Tevfik Paşa in the post of the Grand Vizier. ${ }^{7}$ Although this step calmed down the situation considerably, the coup caused great tension throughout the Ottoman Empire. ${ }^{8}$ The politicians in Vienna (especially the Foreign Minister Count Alois Lexa von Aehrenthal) were quite concerned by the new constellation in Istanbul, but due to their previous effort to improve the mutual relations of both states decided to a cautious observation of future events. Their first task was to ascertain what to expect of the new government. On the day when the Ottoman Constitution was suspended ${ }^{9}$ - the 15 April - Pallavicini visited Tevfik Paşa to discuss future prospects of his government. The Grand Vizier told him, that he and the Sultan ${ }^{10}$ were quite surprised by the turn of events. He also told Aehrenthal, that he wanted to continue in the policy of the previous government with the main goal of restoring the discipline of the army. As a whole he gave quite an optimistic impression - at least according to the Pallavicini's report. ${ }^{11}$

These hopes were however thwarted by a quick and effective counter move of the Young Turk committee residing in Thessalonica. Only two days after his conversation with Grand Vizier both politicians met again. This time Tevfik brought some serious news - the situation in Istanbul created an atmosphere of indignation in Thessalonica. The Young Turks immediately decided to send large quantities of troops from their posts in Macedonia to Çatalca near the Capital. In spite of this Tevfik hoped that he would be able to reach some sort of compromise and he therefore sent a group of parliamentary negotiators in an attempt to persuade the troops to go back to Thessalonica. ${ }^{12}$ This effort was nevertheless hopeless because the Young Turks were adamant. The envoys therefore returned to Istanbul empty-handed because they were detained by the Young Turk soldiers and sent back.

\section{McMEEKIN, 73}

6 Many of the news from the city he received showed up as an exaggeration. HHStA, PA, f. XII Türkei, cart. 198, Berichte, Pallavicini to Aehrenthal, 13. 4. 1909.

7 HHStA, PA, f. XII Türkei, cart. 198, Berichte, Pallavicini to Aehrenthal, 13. 4. 1909, and HHStA, PA, f. XII Türkei, cart. 198, Berichte, Pallavicini to Aehrenthal, 14. 4. 1909.

8 HHStA, PA, f. XII Türkei, cart. 198, Berichte, Pallavicini to Aehrenthal, 14. 4. 1909. Compare with The report of German Foreign Office for Saale-Zeitung, 14. 4. 1909, Die Grosse Politik der Europäischen Kabinette 1871-1914, Johannes LEPSIUS - Albrecht MENDELSSOHN-BARTHOLDY - Friedrich THIMME (eds.), Berlin 1922-1927 (hereinafter referred to only as GP), Vol. 27, 3.

9 MCMEEKIN, 73.

10 The role of the Sultan in the April events was undeniably difficult. According to some sources he acted under the pressure of circumstances. Joan HASLIP, Der Sultan. Das Leben Abd ul-Hamids II., München 1968, $281 \mathrm{ff.}$ Compare with SHAW - SHAW, 281ff. On the other hand the dispatches of the Austro-Hungarian Ambassador speak clearly. According to Pallavicini the insurgency of 13th April was initiated by people from the palace circles who wouldn't act without the knowledge and consent of the Sultan. HHStA, PA, f. XII Türkei, cart. 198, Berichte, Pallavicini to Aehrenthal, 18. 4. 1908.

11 HHStA, PA, f. XII Türkei, cart. 198, Berichte, Pallavicini to Aehrenthal, 15. 4. 1908.

12 HHStA, PA, f. XII Türkei, cart. 198, Berichte, Pallavicini to Aehrenthal, 16. 4. 1909; HHStA, PA, f. XII Türkei, cart. 198, Berichte, Pallavicini to Aehrenthal, 17. 4. 1909. 
The Young Turk officers even issued an order to shoot any envoy from Istanbul attempting to contact them. ${ }^{13}$ The negotiators were only told that the main task of the Macedon army was restoration of the Constitutional law, renewal of order in Istanbul and punishment of the leaders of the rebellion. ${ }^{14}$ In this context the rumours about the possible deposition of the Sultan Abdülhamid II, who was according to the Young Turks responsible for previous events, emerged. However, Pallavicini was convinced that the sovereign would be able to reach an agreement with the Young Turks which was the overall impression of the diplomatic corps in the Ottoman Capital. ${ }^{15}$ The most notable opponent of this opinion was the German ambassador Adolf Marschall von Bieberstein who gained an impression that it was the person of the Sultan, who was the key to most of the current problems of the Ottoman Empire. He therefore reached a conclusion that his fall was inevitable. ${ }^{16}$ Due to these speculations the atmosphere in Istanbul was quite tense. There were more than 15,000 Young Turk troops concentrated on its suburbs on the 19 April 1909 and this number had to reach 40,000 in several days. ${ }^{17}$ This situation provoked a reaction of the Great Powers some of which (especially Great Britain) planned to send warships to the Ottoman coast. ${ }^{18}$

These considerations of a naval demonstration were primarily influenced by wild rumours circulating in Istanbul - when the armoured ships of the Ottoman navy anchored in the Golden Horn on the 21 April, where hearsay spread that if the Macedon troops tried to take the Sultan's residence (Yıldız Palace), the ships would have shelled the Great Power's embassy buildings. ${ }^{19}$ Therefore the anxiety of the Great Powers intervention increased and the Young Turks started therefore to act. On the 22 April they invited the Ottoman deputies in San Stephano to discuss the future of the empire and possible deposition of the Sultan Abdülhamid. Although most of the politicians, who were present, were inclined to make a change on the throne, they didn't issue any final decision in this question, because they feared that such a step would cause uncontrollable riots in Istanbul, which would lead to the Great Power's intervention. ${ }^{20}$ The stance of Vienna during these eventful days was quite reserved and changed considerable only shortly before the final move of the Young Turk forces. On the 23 April Pallavicini talked with the Ottoman Minister of Public Works Gabriel Effendi (who served as Foreign Minister in February and March 1909), whom he told that the best solution of current crisis would be the Sultan's abdication. ${ }^{21}$

At this moment the final solution of the crisis came close. The Young Turk army led by Mahmud Şevket Paşa marched into the capital at night of 23 to 24 April 1909. The anxiety of the Great Powers of the armed clash and the ensuing bloodshed ${ }^{22}$ did not materialize,

13 HHStA, PA, f. XII Türkei, cart. 198, Berichte, Pallavicini to Aehrenthal, 18. 4. 1909.

14 Ibidem.

15 HHStA, PA, f. XII Türkei, cart. 198, Berichte, Pallavicini to Aehrenthal, 20. 4. 1909.

16 According to some reports Abdülhamid initiated the revolt of 13th April by bribing the soldiers of the Istanbul's garrison. HHStA, PA, f. XII Türkei, cart. 198, Berichte, Pallavicini to Aehrenthal, 21. 4. 1909.

17 HHStA, PA, f. XII Türkei, cart. 198, Berichte, Pallavicini to Aehrenthal, 19. 4. 1909.

18 Bülow to the Emperor William II, 21. 4. 1909, GP, Vol. 27, 10.

19 HHStA, PA, f. XII Türkei, cart. 198, Berichte, Pallavicini to Aehrenthal, 21. 4. 1909.

20 HHStA, PA, f. XII Türkei, cart. 198, Berichte, Pallavicini to Aehrenthal, 22. 4. 1909.

21 HHStA, PA, f. XII Türkei, cart. 198, Berichte, Pallavicini to Aehrenthal, 23. 4. 1909.

22 lbidem. 
although some of the troops of the Istanbul garrison defended stubbornly their barracks against the Young Turks. But the situation in the city was surprisingly in order by the morning and the Great Power's legacies (this means even that of Austria-Hungary) were guarded by the Macedonian troops. ${ }^{23}$ The main attention of the ambassadors of the Great Powers concentrated on the destiny of the Sultan Abdülhamid in the ensuing several days until 27 April 1909, when the sovereign was finally deposed. The government of Tevfik Paşa, whom Abdülhamid refused to dismiss, survived only few more days. ${ }^{24}$ Mehmed $V$ Reşad was designated as a new Sultan, although he was described as "morally and physically weakened by alcohol indulging and sexual excess". ${ }^{25}$ Pallavicini did not consider this change as a too important event because he claimed that since Young Turk revolution Abdülhamid's significance diminished considerably and "since that time he wasn't in reality a ruler of this land. His activity was only limited on intrigues against the current regime" ${ }^{26}$ On the other hand the Austro-Hungarian ambassador claimed that the coup of 13 April showed that the true ruler of the Ottoman Empire was not the government, Parliament, or the Young Turk Committee, but the army, which demonstrated that it was not willing to allow itself to be dictated rules by the politicians. All assurance by the army leaders (most prominently Mahmud Şevket Paşa) about the protection of the Constitution was according Pallavicini only "empty phrases". ${ }^{27}$

Austria-Hungary maintained strict neutrality during the crisis and was therefore limited into a role of a mere observer. However Vienna negatively perceived that the crisis led to a tension in the German-British relations. While London showed anxiety of the possible Sultan's deposition with regards to its Muslim subjects in India (the Sultan also held the title of Caliph), ${ }^{28}$ the Germans were increasingly tending to support the Young Turks. Although Abdülhamid was in the previous period a mainstay of German power in Istanbul, ${ }^{29}$ Marschall and his superiors in Berlin did not consider his fall as a major catastrophe. ${ }^{30}$ However it was London which gained more influence in Istanbul in next several years because of the Young Turk leaders' sympathies towards Britain. ${ }^{31}$ On the other hand the position of Austria-Hungary in Istanbul did not change due to its cautious policy, which was determined by the results of the Bosnian annexation crisis. ${ }^{32}$ It could therefore utilize its strengthened position in Istanbul, which gained solution after the crisis.

23 HHStA, PA, f. XII Türkei, cart. 198, Berichte, Pallavicini to Aehrenthal, 24. 4. 1909.

24 HHStA, PA, f. XII Türkei, cart. 198, Berichte, Pallavicini to Aehrenthal, 27. 4. 1909.

25 Eduard GOMBÁR, Moderní dějiny Islámských zemí, Praha 1999, 298. Pallavicini described the new ruler as "a simpleminded and kind-hearted man" and observed that his court would be much simpler because of budgetary cuts. HHStA, PA, f. XII Türkei, cart. 198, Berichte, Pallavicini to Aehrenthal, 5. 5. 1909

26 HHStA, PA, f. XII Türkei, cart. 198, Berichte, Pallavicini to Aehrenthal, 28. 4. 1909.

27 HHStA, PA, f. XII Türkei, cart. 198, Berichte, Pallavicini to Aehrenthal, 28. 4. 1909.

28 To the question of the character of the Ottoman Caliphate see Selim DERINGIL, The Well-Protected Domains. Ideology and the Legitimation of Power in the Ottoman Empire 1876-1909, New York 2011, 46-50.

29 MCMEEKIN, 37.

30 HHStA, PA, f. XII Türkei, cart. 198, Berichte, Pallavicini to Aehrenthal, 28. 4. 1909.

31 MCMEEKIN, 77.

32 This stance of Vienna was determined by Aehrenthal's conviction that after the annexation of Bosnia and Herzegovina Austria-Hungary had to return to its previous policy of status quo. Rubina MÖHRING, Die Beziehungen zwischen Österreich-Ungarn und dem Osmanischen Reich 1908-1912, Diss., Wien 1978, 60. 
The situation in the Ottoman capital remained restless during the remainder of the 1909. After his return from vacation in June 1909 Pallavicini even claimed that the conditions had even worsened, and in his dispatches he described that the Young Turk officers had gained the upper hand in the Ottoman army. ${ }^{33}$ The calming came at the end of the year thanks to the effort of the new government which was able to stabilize the budget which managed with surplus for the fiscal year 1909/1910 (1325 according to the Islamic calendar). Pallavicini stated that this state of affairs was enabled by the Austro-Hungarian compensation for the annexation of Bosnia and Herzegovina and the confiscation of the properties of the deposed Sultan in the high of 1.6 million Turkish pounds. ${ }^{34}$ In spite of this Pallavicini's reports were pessimistic in this period due to the inner political steps of the Young Turks. It was above all the purges in the army and civil service which were initiated after the defeat of the 13 April insurrection. The Ottoman public life and the power of the palace were then considerably changed by the adjustment of the Constitution which occurred on 21 April 1909. ${ }^{35}$ Other important steps of the Young Turks were the limitation of liberty of speech and assembly by the laws concerning press and strikes issued on 9 August. ${ }^{36}$ The Young Turk regime started a process of gradual strengthening of its power.

The spring and summer events of 1909 had some considerable impacts on the international scene. Most importantly Pallavicini noticed a change of Russian stance towards the Ottoman Empire. With the appointment of Nikolai Tcharykov as a new ambassador to Istanbul, the Russians started to support the Young Turk regime. In the talks with Pallavicini the Russian diplomat said that Russia hoped not only in economic but also political cooperation with the Porte. Therefore Pallavicini was at first concerned of possible recurrence of the Russian idea of creation of an alliance of Balkan states directed against Austria-Hungary which firstly appeared at the beginning of the Bosnian crisis, but after a thorough consideration he came to a conclusion that such project was only a "Potemkin village". ${ }^{37}$ In reality the motives of Russian policy towards the Ottoman Empire were quite different. According to Tcharykov, who explained them to Izvolski's successor in the post of the Foreign Minister Sergei Sazonov that Russia had to hinder possible breakup of the Ottoman Empire until it was advantageous to its interests and it would be able to profit from this development. ${ }^{38}$ The Ottoman Empire should therefore due to the interests of the Great Powers enjoy some sort of security despite the rumours of threatening Greco-Ottoman war which emerged during the summer 1909.39

The situation in the Ottoman Empire somewhat calmed down in the period since the summer 1909 till the autumn 1911 when the Italo-Ottoman war triggered a major crisis of the Eastern Question. Despite of this Austria-Hungary had to solve several important problems in its relation toward the Ottoman Empire. One of them was the Cretan question, because

33 HHStA, PA, f. XII Türkei, cart. 198, Berichte, Pallavicini to Aehrenthal, 23. 6. 1909.

34 HHStA, PA, f. XII Türkei, cart. 198, Berichte, Otto to Aehrenthal, 16. 6. 1909.

35 SHAW - SHAW, pp. $284 \mathrm{ff}$.

36 M. Şükrü HANIOĞLU, A Brief History of the Late Ottoman Empire, Princeton - Oxford 2008, 155.

37 HHStA, PA, f. XII Türkei, cart. 198, Berichte, Pallavicini to Aehrenthal, 28. 7. 1909.

38 Michael A. REYNOLDS, Shattering Empires. The Clash and Collapse of the Ottoman and Russian Empires, Cambridge 2011, 29.

39 HHStA, PA, f. XII Türkei, cart. 198, Berichte, Pallavicini to Aehrenthal, 21. 7. 1909. 
the island declared its accession to Greece after the Young Turk revolution. ${ }^{40}$ The anxiety of the Great Powers of the possible conflict and Russia's reluctance to support Greek aspirations ${ }^{41}$ caused the postponement of the solution of this problem till the end of the Balkan wars. Austria-Hungary didn't engage in the Cretan question, because it wanted to maintain its good relations with the Porte despite the fact it was the main commercial partner of the island. ${ }^{42}$ Austria-Hungary could utilize the fact, that it wasn't taking part on the occupation of Crete by the Great Powers and could therefore take side of Istanbul during the controversy. ${ }^{43}$ The same stance observed also Berlin which claimed that the international law was on the side of the Ottoman Empire. ${ }^{44}$ Aehrenthal pursued this course of his policy even during 1910 when the Cretan Greek tried to enforce their rule on the island. ${ }^{45}$ This Austro-Hungarian indifference was caused not only by the policy of maintain good relations with the Turks but also by Aehrenthal's concern about the situation in Macedonia and Albania. ${ }^{46}$

This cautious policy paid off because during the second half of the 1909 the contemporary observers registered considerable strengthening of the Austro-Hungarian influence in Istanbul. Already in August Pallavicini could observe that the rupture of mutual relations which occurred during the Bosnian crisis was the question of the past. ${ }^{47} \mathrm{He}$ benefited not only from the overall situation in Istanbul, but was also able to utilize the fear of the Turks of the mutual understanding of Britain and Russia about the question of the Straits. ${ }^{48}$ Therefore the Austro-Ottoman relations tended to improve to such a degree that some historians even claim that the Turks tried to enter into an alliance with the Dual monarchy. ${ }^{49}$ However, the reality was much more complicated than this. It is true that at the turn of the years 1909/1910 the Turks tried to reach some sort of settlement on the basis on entente with Austria-Hungary ${ }^{50}$ mainly due to the collapse of Russian idea of Balkan league led by the Ottoman Empire. ${ }^{51}$ As for the claims of the idea of the Austro-Ottoman alliance, it must

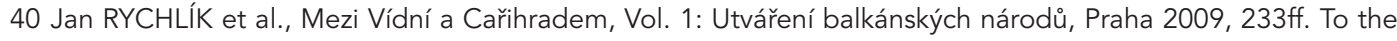
Cretan question see also. Wangenheim to Bülow, 23. 6. 1909, GP, Vol. 27, 64-68.

41 HHStA, PA, f. XII Türkei, cart. 198, Berichte, Pallavicini to Aehrenthal, 21. 7. 1909.

42 Francis Roy BRIDGE, From Sadowa to Sarajevo. The Foreign Policy of Austria-Hungary 1866-1914, London Boston 1972, 325.

43 MÖHRING, 64.

44 Miquel to Bethmann Hollweg, 16. 7. 1909, GP, Vol. 27, 71.

45 BRIDGE, 326.

46 Aehrenthal's memoire 15. 8. 1909, Österreich-Ungarns Aussenpolitik von der bosnischen Krise 1908 bis zum Kriegsausbruch 1914. Diplomatische Aktenstücke des österreichisch-ungarischen Ministeriums des Äussern (hereinafter referred to only as ÖUA), Ludwig BITTNER - Alfred Francis PRIBRAM - Heinrich SRBIK et al. (eds.), Vol. 2, Wien - Leipzig 1930, 443.

47 HHStA, PA, f. XII Türkei, cart. 199, Berichte, Pallavicini to Aehrenthal, 28. 8. 1909.

48 HHStA, PA, f. XII Türkei, cart. 199, Berichte, Pallavicini to Aehrenthal, 19. 8. 1909. This anxiety was ill-founded, because Russian military leadership advised with further steps for the reconstruction of the Russian navy. Ronald P. BOBROFF, Roads to Glory. Late Imperial Russia and the Turkish Straits, London - New York 2006, 17.

49 BRIDGE, 324.

50 MÖHRING, 67.

51 HHStA, PA, f. XII Türkei, cart. 199, Berichte, Pallavicini to Aehrenthal, 15. 12. 1909. To this Russian policy see REYNOLDS, 31. 
be stressed, that both sides were quite careful and the Turks limited themselves on some vague hints. At the end of 1909 Hilmi Paşa in a conversation with Pallavicini denied that the Ottomans intended to ally themselves with some other power by which he probably tried to disperse Austro-Hungarian anxiety of the possible Balkan League. ${ }^{52} \mathrm{New}$ Ottoman diplomatic probes concerning possible improvement of mutual relations occurred after the accession of Ibrahim Hakkı Paşa to the post of the Grand Vizier on the 12 January 1910. However, the bad situation in Istanbul compelled Aehrenthal to observe that "the political situation of the Turkish empire is not clear enough for us to make political deals with it". ${ }^{53}$ The idea of the Austro-Ottoman entente was definitively ended by the threat of a war between the Ottoman Empire and Bulgaria in the spring 1910. ${ }^{54}$ Although no agreement was ever reached, Pallavicini stated that the prestige of Austria-Hungary in Istanbul surpassed that of Russia. ${ }^{55}$ However if the policy of Vienna in this period is thoroughly analysed, it must be claimed that the possibility of the Austro-Ottoman alliance was out of the question, because such step would irredeemably shattered the position of Austria-Hungary in other Balkan states. ${ }^{56}$

The relatively strengthened position of Vienna in Istanbul was soon disrupted by the inner situation of the Ottoman Empire. The Great Powers concentrated themselves primarily on Macedonia, but the instability started to spread even to Albania, whose representatives hoped that after the deposition of the Sultan Abdülhamid their national demands would be satisfied. When such thing did not materialize, the situation in the region became disturbing. ${ }^{57}$ Since the beginning of 1909 the Albanian members of the Ottoman Parliament were in the opposition. ${ }^{58}$ Some several rebellions even broke out in Albania during summer 1909, but the Turks suppressed them easily. However the hard treatment of the insurgents led to the uprising of the Malissor tribes professing Catholic religion. ${ }^{59}$ This got Vienna into a difficult situation because on the one hand it didn't want to lose its position in Istanbul, but on the other by ignoring the situation in Albania it could lose its cultural protectorate over local Catholic population which it held since the end of the 17th century. Vienna was also aware of the danger that its inactivity could be utilized by Italy who became to be a rival of Austria-Hungary in Albania. ${ }^{60}$ Pallavicini therefore advised caution, because he was aware, that the situation in Albania could harm the prestige of the Habsburg monarchy on the Balkans ${ }^{61}$

52 HHStA, PA, f. XII Türkei, cart. 199, Berichte, Pallavicini to Aehrenthal, 22. 12. 1909.

53 Instruction from the Austro-Hungarian Foreign Office to the ambassador in Istanbul, 13. 1. 1910, ÖUA, Vol. $2,649$.

54 HHStA, PA, f. XII Türkei, cart. 200, Berichte, Pallavicini to Aehrenthal, 5. 2. 1910.

55 HHStA, PA, f. XII Türkei, cart. 200, Berichte, Pallavicini to Aehrenthal, 9. 2. 1910 and 11. 2. 1910.

56 In the military circles of the Habsburg monarchy it was the chief of the General Staff Conrad von Hötzendorf who was willing to establish cooperation with the Ottoman Empire. Franz CONRAD VON HÖTZENDORF, Aus meiner Dienstzeit 1906-1918, Vol. 2, Wien 1922, 30.

57 RYCHLík et al., 317ff.

58 HHStA, PA, f. XII Türkei, cart. 198, Berichte, Pallavicini to Aehrenthal, 23. 1. 1909 and 27. 1. 1909.

59 Aleš SKŘIVAN, Císařská politika. Rakousko-Uhersko a Německo v evropské politice v letech 1906-1914, Praha $1996,136$.

60 lbidem, $136 f f$.

61 HHStA, PA, f. XII Türkei, cart. 201, Berichte, Pallavicini to Aehrenthal, 27. 4. 1910. 
Therefore the policy of Vienna towards the Albanian question started to change. Although the Austro-Hungarian financial institutes joined the German banks in a loan of 11 million Turkish pounds to the Porte, ${ }^{62}$ Ballhausplatz started a pressure on the Porte with the aim of solving the Albanian question. Aehrenthal therefore instructed Pallavicini to tell the Turks, that maintaining peace on the Balkans was in their own interest. ${ }^{63}$ In the spring $1910 \mathrm{Vi}-$ enna came to a conclusion that the strengthening of the Albanians was in its own interest because they could have been used as a barrier against the Balkan Slavs. ${ }^{64}$ In this policy Austria-Hungary was supported by the German ambassador Marschall, who told the Grand Vizier Hakki Paşa that the anti-Albanian stance complied with the interests of Russia. ${ }^{65}$ This effort can be traced even in the diplomacy of Italy. ${ }^{66}$ This change of the Austro-Hungarian stance towards the Ottoman Empire and the Italian effort to meddle into the situation in Albania led the Turks to concern about the possibility of the intervention of the Great Powers, ${ }^{67}$ but nor Vienna nor Rome plucked up the courage to intervene and the rebellion was drowned in blood. At the end of August could Mahmud Şevket Paşa claim that the Ottoman troops were in the control of the region? ${ }^{68}$

The seemingly calmed situation in Albania enabled restoration of good Austro-Ottoman relations. This was demonstrated by the visit of the Grand Vizier Hakki Paşa in Marienbad where he negotiated with Aehrenthal on 15 and 16 August 1910.69 Some sources even state that the Turks were trying during the meeting to attach the Ottoman Empire to the Triple Alliance. ${ }^{70}$ This claim can be labelled as bold, but it must be stressed that the negotiations of Marienbad can be considered as one of the climaxes of the Austro-Ottoman relations. Both politicians discussed above all the problems of the Balkans and the stance of their countries towards them. As for the situation in Albania Aehrenthal expressed his satisfaction that the situation calmed down and expressed his hope that after the pacification of the region "the Turks would be able to gain the very important Albanian element on their side", because the continuation of the conflict would only satisfy the Russian interests. ${ }^{71}$ The next topic of the discussion was the relation of the Ottoman Empire towards the Balkan states and the solution of the Cretan question, which was still acute in the middle of 1910. Hakki Paşa then summarized the stance of the Porte towards individual Great Powers. He stressed that the distrust of the Ottomans towards Russia increased after St. Petersburg had signed a treaty with Tokyo solving the problems of both states on the Far East, which signalled, that Russia's attention would focus on the Balkans. ${ }^{72}$ As for the

62 This loan was definitely approved in November 1910. SKŘIVAN, 136.

63 Pallavicini to Aehrenthal, 26. 3. 1910, ÖUA, Vol. 2, 777.

64 MÖHRING, 72.

65 HHStA, PA, f. XII Türkei, cart. 201, Berichte, Pallavicini to Aehrenthal, 30. 4. 1910.

66 HHStA, PA, f. XII Türkei, cart. 201, Berichte, Pallavicini to Aehrenthal, 19. 5. 1910.

67 HHStA, PA, f. XII Türkei, cart. 201, Berichte, Pallavicini to Aehrenthal, 18. 5. 1910.

68 HHStA, PA, f. XII Türkei, cart. 202, Berichte, Pallavicini to Aehrenthal, 25. 8. 1910.

69 Record of the meeting with Hakki Paşa, 15. and 16. 8. 1910, ÖUA, Vol. 2, 930-936.

70 MÖHRING, 81.

71 Record of the meeting with Hakki Paşa, 15. and 16. 8. 1910, ÖUA, Vol. 2, 931.

72 lbidem, 935. 
economic questions Hakki Paşa asked Aehrenthal for support in the question of increasing the Ottoman trade tariffs by $4 \%$ which was the aim of the Ottoman policy since $1908 .{ }^{73} \mathrm{As}$ a whole the meeting was conducted in a friendly atmosphere and strengthened the relations of both states, but despite of that Aehrenthal did not provide any binding statement. The good relations of both countries persisted till the end of 1911 when the position of Austria-Hungary in the Ottoman Empire started to wane.

Considerable rupture between Vienna and Istanbul can be traced to the repeated rebellion in Albania, organized by nationalist group called Black Society for Salvation, which broke out in 1911. ${ }^{74}$ The situation in Albania caused anxiety of Vienna of possible intervention of the Balkan states, which could cause the collapse of the Ottoman rule in Europe. Aehrenthal was especially concerned about the policy of Serbia and Montenegro which ambitions he considered as the most dangerous. Therefore he even considered considered the possibility of opening negotiations with the Porte about the reoccupation of the Sanjak of Novi Pazar by the Austro-Hungarian troops. ${ }^{75}$ But the policy of Austria-Hungary remained careful and somewhat passive, which can be attributed to Aehrenthal's illness during which Pallavicini temporarily directed the Austro-Hungarian Foreign Office ${ }^{76}$ and didn't risk making radical political steps. The policy of the Habsburg monarchy activated after Aehrenthal's return in May 1911, when Vienna vehemently advised the Porte to secure peace in Albania. ${ }^{77}$ When this didn't happen, Vienna oriented itself on the support of the Albanians, which cooled down the mutual relation between Austria-Hungary and the Ottoman Empire, which manifested most notably during an Ottoman boycott of Austro-Hungarian shipping companies. ${ }^{78}$ However the danger of the escalation of the situation in Albania was obvious even to the Turks. Therefore in June 1911 the Sultan in a company of the Grand Vizier and many other Ottoman dignitaries visited Albania. ${ }^{79}$ This step somewhat calmed the situation down. After his return the sovereign was welcomed by huge crowds manifesting their sympathies to him. However Pallavicini noticed that these demonstrations were limited mainly on the Muslim population of the city, which he explained as a result of the Islamic policy of the government. ${ }^{80}$ The standstill in Albania was however only temporary because shortly after the Sultan returned to Istanbul Pallavicini obtained information about new demonstration in southern part of the region. ${ }^{81}$

During the summer 1911 the attention of Vienna slowly moved from the Albanian question towards the worsening of the Italo-Ottoman relations. ${ }^{82}$ The Albanian question lost all of

73 However this increase was finally realized in 1914. The question of the Ottoman trade tariffs is not to be underestimated, because it represented $19 \%$ of Ottoman state income. Halil iNALCIK - Donald QUATAERT (eds.), An Economic and Social History of the Ottoman Empire, Vol. 2, 1600-1914, Cambridge 2004, 826ff.

74 RYCHLíK et al., 319.

75 MÖHRING, $87 \mathrm{ff}$.

76 SKŘIVAN, 145.

77 MÖHRING, 93.

78 Ibidem, 95.

79 HHStA, PA, f. XII Türkei, cart. 205, Berichte, Kolossa to Aehrenthal, 5. 6. 1911.

80 HHStA, PA, f. XII Türkei, cart. 205, Berichte, Pallavicini to Aehrenthal, 1. 7. 1911.

81 HHStA, PA, f. XII Türkei, cart. 205, Berichte, Pallavicini to Aehrenthal, 15. 7. 1911.

82 HHStA, PA, f. XII Türkei, cart. 205, Berichte, Pallavicini to Aehrenthal, 21. 7. 1911. 
a sudden its importance, because the increasing possibility of war between Italy and the Ottoman Empire represented major problem of the orientation of the Austro-Hungarian policy. The success of Austria-Hungary in enforcing its interests in Istanbul during the years 1909-1910 was only temporary. Already the Albanian revolt led to important rupture of mutual relations and the additional worsening of the position of Vienna in Istanbul should follow in next month, although in summer 1911 the relations of both states temporarily improved due to the financial help of Austria-Hungary after the great fire of Istanbul on the 23 to 24 July $1911 .{ }^{83}$ However, the period of cordial relations of both states ended by the fall 1911 and the good relation in the years of 1909-1910 remained unutilized by Vienna, which became more evident in next two years when its position on the Balkans collapsed all of a sudden.

\section{Abstract}

After the end of the Bosnian annexation crisis Austria-Hungary was able to improve its position in the Ottoman Empire. This was enabled not only due to successful negotiations with the Porte which enabled the solution of the crisis, but also by the cautious policy of Vienna during the coup of 13th April in Istanbul. During the second half of 1909 Austria-Hungary was able to considerably improve its relations with the Ottoman Empire. Although Vienna was able to profit from this fact in some cases as a whole the favourable situation was not utilized to improve the stance of the Habsburg monarchy on the Balkans. Since the second half of 1910 the relations of both states were disturbed by the repeated revolts in Albania. The effort of Austria-Hungary to force the Porte to reach some sort of deal with the Albanians was in vain. Moreover in the second half of 1911 the mutual relations of both states were considerably worsened and complicated by the outbreak of the Italo-Ottoman hostilities.

\section{Keywords}

Austria-Hungary, Ottoman Empire, Russia, Balkans, diplomacy, international relations 